\title{
Process Drama as a tool for teaching Modern Languages: supporting the development of creativity and innovation in early professional practice
}

\section{Bethan Hulse \& Allan Owens}

\author{
Faculty of Education and Children's Services, University of Chester
}

\begin{abstract}
This paper reflects on issues arising from a research-informed learning and teaching project intended to enable student teachers of Modern Languages (MLs) to experiment with the use of unscripted 'process drama' in their classroom practice. The idea that process drama could become part of the language teacher's repertoire has been in circulation for some time (Kao and O’Neill, 1998; Bräuer, 2002; Fleming, 2006; Stinson and Freebody, 2006; Giebert, 2014) yet there is little evidence to suggest that its use has become widespread in schools in England. The aim of the project was to enable student teachers to acquire drama teaching techniques which they could incorporate into their own practice in order to enrich the learning experiences their students through creative and imaginative use of the foreign language in the classroom. The research was undertaken over a period of three years by two teacher educators on a secondary initial teacher education programme in a university in England. The paper concludes that it is both possible and desirable for student teachers to encounter alternative approaches which challenge the norm and that with support they may develop innovative practices which can survive the 'the 'crucible of classroom experience' (Stronach et al. 2002, p.124).
\end{abstract}

\section{Introduction}

There is a growing body of international research evidence which indicates that process drama can be an effective tool for promoting the spontaneous production of language within the context of additional language learning (Kao and O’Neill, 1998; Liu, 2002; Fleming, 2006; Stinson and Winston, 2011; Giebert, 2014). However, there is little evidence to suggest that its use is commonplace. The seminal practice-based study conducted by Kao and O'Neill (1998) points to two reasons for this. Firstly that teachers do not see how learners would be able to participate in an unscripted drama with very limited foreign language skills, secondly, teachers, constrained by a culture of testing, emphasise accuracy over fluency and are too quick to jump in with corrections which 'inhibit students from entering dramatic worlds' (Kao and O'Neill, 1998, 
p.28). We suggest a third reason, that student teachers are unlikely to be able to sustain a form of innovative pedagogy which directly challenges existing conventional practices, hierarchies of power associated with these (DeCoursey, M. and Trent, J. 2016, p.537) and the resultant challenges to their emerging professional identity.

The early formative experiences of student teachers are known to have a significant impact on subsequent practice and on the formation of a sense of a professional self (Day et al., 2007). At this early stage, when this sense of a professional identity is often very fragile (Hargreaves, 2002), student teachers look to their more experienced mentors for models of 'good teaching' which they may feel compelled to emulate (Jones, 2000; Tickle, 2001). The models of teaching on offer are becoming increasingly instrumental and defined by constraining cultures of performativity (Ball, 2003) which, it is argued, have an adverse effect on creativity and professional autonomy (Robinson, 2011; Adnett \& Hammersley-Fletcher, 2009).

Process drama presents student language teachers with a very different pedagogical model to that which is the norm within the ML classroom, requiring them to step into uncertain territory, often without the support of models provided by the mentor, venturing beyond the unwritten pedagogical boundaries of language teaching into the very different terrain of imagined experiential learning. Taking the view that student teachers are often more open to innovative practice than established practitioners (Trent, 2014), we sought explore how the circle of existing pedagogical practices might be shifted in the formative years of student teaching in ways that might be sustainable.

The aim of the research was to reflect on the experiences of student teachers' experimentation with process drama both in university and during their school practicum. Evidence is drawn from interviews with ML and drama student teachers as well as our own reflections and observations as teacher educators. The views of young language learners and mentors participating in the ML/drama projects were also sought. Issues arising from analysis of the data focus on attitudes and dispositions which facilitate an openness to experimentation with innovative, interdisciplinary approaches. We suggest that the conflicts and discomforts this evokes can become fertile ground for new ideas to emerge. 


\section{Context}

The research was conducted with three successive cohorts of student teachers on a one year postgraduate Initial Teacher Education (ITE) programme in a University in England. The programme prepares student teachers to teach French, German or Spanish at secondary level (students aged 11-18).The context for learning foreign languages in England presents particular challenges for teachers and learners. Most significantly these concern the motivational aspects of learning a language other than English (Dörnyei, 2001; Enever, 2009). Modern Languages are optional after the age of fourteen and fewer than half of all students choose to continue learning a language after this age. This is often attributed to the perception that MLs are both difficult (Coleman, 2007, p.252) and unnecessary as English is widely spoken across the world. However, concerns have also been raised about the curriculum content and the lack of creativity in current practice. The schools' inspectorate for England identifies teachers' use of textbooks at the expense of real communication as being problematic (The Office for Standards in Education (Ofsted) 2011). The lower status of MLs in England means that less curriculum time is devoted to their study than in most other European countries, with the average time allocation being just over two hours per week (CILT, 2009). With so little time available, teachers often feel that creativity must be sacrificed in order to cover the content required by external examinations. In England, the ability to perform pre-learned phrases has taken precedence over the spontaneous and creative use of language (Pachler et al., 2007, p.91), which has been identified as a weakness in secondary education:

'where inspectors observed students speaking, this was generally prepared, for example written role plays. Too much speaking still relied on writing, thus hindering the development of spontaneous talk.' (Ofsted, 2011, p.24).

Effective language learning requires opportunities for authentic verbal interactions (Mitchell, 2003) which allow learners to progress from familiar to unfamiliar contexts and require them to produce language 'on the spot' (Harris et al., 2001). However, within the traditional languages classroom the scope for learners to do this is limited due to the emphasis placed on 'practising language rather than expressing personal meanings and identities' (Ushioda, 2011, p.227).This 
results in the production of 'pseudo -communication' which is de-motivating for the learner (ibid.). Process drama, we argue, has the potential to address all of these deficiencies.

We acknowledge that these particular constraints do not necessarily apply in other countries or contexts. Our experiences of working on cross curricular ML/drama projects with teachers and students in English language classrooms in the Netherlands and in Spain and with ML teachers in Austria (Pochazka, 2007) have provided us with rich opportunities to develop our ideas where the interdisciplinary approach we are advocating is more commonplace. Transferring these ideas into the English context where schools often appear to be organized like 'factories for learning' (Robinson, 2011, p.55) presents particular challenges for teachers and for those responsible for their early education. It was our explicit intention that the ML/drama project might provide spaces where student teachers could experiment with alternative approaches which encompass a wider view of learning and where creativity might be experienced in a real and meaningful way.

\section{Process Drama and Additional Language Learning}

Process drama opens the possibilities of learning through imagined experience (Neelands, 1992), and, in the context of this project specifically, through the provision of a meaningful context for spontaneous language production. Participants are invited to play, to act spontaneously and to engage their imagination as they step into a co-constructed, imagined drama world (O'Neill 1995). During the course of this project, it has become evident to us that young language learners respond very positively to opportunities to co-create the dramatic narratives that bring these worlds into being. The student teachers are invited to reflect on the seriously playful and playfully serious' (Heikkinen, 2005, p.51) intentions behind the fun and enjoyment, the key one in this context being to provide opportunities for learners to develop their ability to communicate in another language and to be motivated to do so. Our ideas emerged initially through working with groups of student teachers in university sessions which took the form of practical workshops. Some of these involved just ML student teachers and some where both ML and drama student teachers worked together. As ideas evolved, ML student teachers began experimenting with them in the classroom, supported by university tutors and by their drama peers. Student teachers were encouraged to take from the sessions whatever they felt was useful 
to them, from drama games and discrete activities designed to develop the four language skills, to a complete one hour process drama session. It was important to consider how innovative approaches might be assimilated into teaching methods which were more familiar to them, and which would be more likely to meet with the approval of their mentors.

The use of drama in Modern Language (ML) teaching is not uncommon, but often takes the form of a performance of a prepared script, not too far removed from the traditional 'role play'. Process drama, on the other hand, is an open-ended, creative pedagogical practice which is at one end of a 'continuum' of drama approaches in language teaching and learning with scripted performance and 'role play' at the other end (Kao and O’Neill, 1998). As Giebert points out, however, this does not mean that such an open-ended form cannot shift into script; much depends on context. Giebert quotes Liu (2003. p.55) in defining process drama as 'a term widely used in North America (but originally from Australia) .....concerned with the development of a dramatic world created by both the teacher and the students working together.' In this project we use a particular form of pre-text based process drama. On one level 'pre-text' is taken to mean an excuse to learn, on another as the text which precedes that of the participants who exercise agency through the process of creating their own text (O’Neill, 1995; O'Toole, 1992). This draws on Dorothy Heathcote's conceptualisation of drama education as a form of collaborative storytelling where participants are taken through a 'drama discovery where the outcomes are in the balance but decided finally by those involved' (Heathcote in Drain, 1995, p.203).

In the ML context we keep these key elements of pre-text based process drama firmly in sight, together with others including the use of dramatic tension to engage participants. The pre-text is composed of a carefully arranged series of drama conventions to structure participation whilst simultaneously allowing for spontaneity (O’Neill, 1995). Drama conventions are ways of organizing time, space and action to create meaning, allowing all members of the group to participate in the drama in an organized and challenging way. Different conventions allow for different levels of participation, moving between watching, listening and doing (Boal, 1995). They create opportunities for individuals to consider their thoughts, emotions, feelings and understandings in relation to the rest of the individuals in the group (Adams and Owens, 2016). 
The introduction of an imaginary, fantastical context for talk can create a desire to communicate which overrides the learner's fear of linguistic inadequacy, enabling them to make the best use of the language they already know (Sommers, 1994, in Chang, 2012, p.8) and share their knowledge with others. Our findings suggest that even learners with a very limited knowledge of the foreign language can, with appropriate linguistic scaffolding, participate in an open-ended process drama. This is because it introduces emotional and physical elements into language learning which are often missing (Bräuer, 2002; Rothwell, 2011, p.578). Communication becomes possible through a continuum of verbal and non-verbal responses, allowing sophisticated thought processes to occur within a limited range of language. A study by Rothwell (2011) illustrates how beginner language learners were able to engage in 'higher order and intellectual themes' using a very narrow range of German language. She demonstrates how a single word (Nein!) was 'milked' for 'every ounce of meaning using repetition, hesitation, intonation, stress, speed, pause and gesture' (p.581).

One of the main concerns for language teachers in introducing process drama is the risk of failure if the learner is not equipped with the language required. Kao and O'Neill (1998) note that language teachers are often sceptical regarding the ability of learners to engage in a complex drama with limited language. The key to successful implementation therefore lies in matching the linguistic demands of the drama with the prior knowledge and abilities of the students.

Rothwell documents her own dilemmas in balancing the demands of 'dramatic imperatives' with the need to focus on the relevant linguistic forms (p.591). Dunn and Stinson conclude from their study of two drama/ML projects that the main barrier to success is the inexperience of language teachers in managing dramatic form (Dunn and Stinson, 2011, p. 619). They argue that 'it is only when teachers/facilitators are able to hold both the artistry of the form and the intended learning in one hand, as it were, that the full promise of working with drama and additional language learning can be realised' (ibid., p.618).

\section{Student teacher identity}

Process drama presents a significant challenge for the student ML teacher in that it is dialogic, student- centred and incorporates dramaturgical forms of 'self-other imagining' in open-ended 
learning situations where the teacher is often co-learner (Neelands, 2002, p.6). It requires the teacher to 'assume functions which go beyond the more usual ones of an instructor, model and resource' (Kao and O’Neill, 1998, p.1), moving away from a teacher-centric approach to more 'horizontal' relationships (Freire, 1972). A key issue arising from the research is therefore that of the emergent student teacher's professional identity. Stronach et al. (2002) propose that professionalism is a juggling act between 'economies of performance' (defined as manifestations of the audit culture such as exam results, state prescribed curriculum and pedagogy) and 'ecologies of practice' (defined as professional dispositions and commitments engendered collectively and individually) (Stronach et al., 2002, p.109). It is within the tensions generated between these two 'disparate allegiances' that that the professional is able to develop a real understanding of their work and belief (ibid.p.122). Stronach draws on a longitudinal study of beginning teachers (ESRC project 'Early Professional Learning') to argue that a 'chasm' appears between what is seen as the 'generic and idealised' features of preparation and the 'unpredictable and singularised' demands of real performance (Stronach, 2009, p168). It is however, necessary for the student teacher to experience the gap between the 'possibilities of induction' (or preparation) and the 'experiences of initiation' (or practical reality) wherein lies the 'place of invention' (ibid., p.165).We have taken this interpretation of early professional development as a lens with which to examine student ML student teachers' experiences of experimenting with process drama. The ML/Drama project was intended to open up possibilities which challenge the 'norm' and in so doing create a space for the invention of a positive sense of a professional self. Experimentation with process drama required them to take risks and to be open to the possibility of failure, but also allowed them to experience a sense of professional autonomy.

Stronach concludes from his research that such tensions mobilise a 'shifting, plural and contradictory sense of the professional self as an uncertain being'. Student language teachers often experience a sharp conflict between their personal experiences and beliefs about language learning (relating to ecologies of practice) and ML as a school subject (relating to economies of performance). They are motivated by a love of other languages and cultures and invariably express a strong desire to share their language skills and personal experiences of living and working abroad with their students. When they arrive in school they must transform this body of personal knowledge into a school subject, a 'field of knowledge for others to acquire' (Pachler et 
al., 2007, p.47). This process is, according to Pachler et al., more complex for ML student teachers than for student teachers of other subjects due to the 'unique pedagogical dimensions' of the subject. One of the principle aspects of this being that the subject matter (the foreign language) is also the medium through which the students learn (Macaro, 2003, in Pachler et al., 2003, p.56). This collision of economy and ecology often prompts the student teacher to take refuge in a narrow specification of subject content because of the certainty it appears to offer (Stronach et al., 2002, p.124). Whilst our project was intended to support the development of a broader pedagogical repertoire, we were very aware of both the risks for student teachers venturing outside accepted subject boundaries which they themselves have not yet fully experienced and the challenges for teachers who have not yet established a secure professional identity (Day et al., 2007).

\section{Project outline}

In developing our ideas for introducing ML student teachers to process drama, our guiding principle was that the emerging pedagogy should be robust enough to survive the "crucible of classroom experience' (Stronach et al. 2002, p.124) where innovations are 'tested, adapted, resisted, embraced or ignored' (ibid.). Trent (2014) draws attention to the importance of supporting the implementation process in language teaching innovation. Drawing on Markee (2001), he points out that without such support innovations are doomed to failure (Trent, 2014, p. 56). Cognisant of the challenges our student teachers would confront in introducing an innovative practice during their school practicum, we planned and implemented a series of workshops to support them. We drew on drama and ML theory as well as our own experiences of working with student teachers and of teaching our subjects in different contexts. This interdisciplinary dimension was a key feature of the project as 'a deep understanding of the two disciplines maximises the outcomes achieved' (Dunn and Stinson, 2011, p.619). We would, however argue that fundamental differences between the pedagogical approaches of two disciplines pose significant challenges for ML practitioners. One of the cornerstones of ML pedagogy, the Presentation, Practice Production model (Littlewood, 1984) exemplifies an approach which is predominantly teacher-led and focuses on predictable and precise linguistic outcomes. The contrast between this and the dialogic approach which underpins process drama 
could hardly be starker. The ML teacher must adjust their practice to accommodate less teachercentric roles as well as allowing for unpredictable outcomes along a continuum of verbal and non-verbal communication. As experienced practitioners with a secure knowledge of our own subject disciplines this was easier to manage than for our student teachers. The success of the project was therefore dependent upon the provision of scaffolds for their professional learning. With this in mind, we introduced students to basic drama conventions such as 'hot-seating' and 'teacher in role' (Owens and Barber, 2001) within linguistic contexts drawn from the National Curriculum for Modern Languages. We invited student teachers to contrast the conventional 'unframed' role play with a 'framed' role play which has the same linguistic elements but has an enjoyable dramatic tension, producing a compelling reason to communicate. We suggested to them (through practical illustration) that without the dramatic tension supplied by having perspective and a clear focus, the traditional 'unframed role play' often fails to engage learners. The 'framed role play' enables the learner to engage emotionally and physically as well as intellectually.

\section{Figure 1: Unframed role play}

\begin{tabular}{|c|c|}
\multicolumn{1}{c|}{ Role } \\
\cline { 2 - 3 } & \multicolumn{1}{|c|}{ set dialogue } \\
Blurred Focus & Context confined to classroom \\
& Practice of new language \\
\hline
\end{tabular}




\section{Figure 2: Framed role play}

\begin{tabular}{|l|l|}
\hline \multicolumn{1}{|c|}{ Role } \\
Clear focus & $\begin{array}{l}\text { Metaphor } \\
\text { Range of contexts } \\
\text { Creative use of language } \\
\text { Purposeful communication }\end{array}$ \\
\hline & Perspective
\end{tabular}

Students were offered materials to support their experimentation in the form of discrete one hour ML lessons adapted from pre-texts (Owens and Barber, 2001) written for drama lessons but with clearly mapped linguistic content. The sample lesson plan in Figure 3 was created through effective and deceptively simple use of conventions (Fleming, 2001, p.34) including physical theatre, teacher in role and letters. Classroom experiments were successful in terms of language production and learner engagement but the 'dramatic process' was, of necessity, far less open and more controlled than it would be in a drama lesson. Figure 3 illustrates both the linguistic possibilities and the 'dramatic' limitations of our approach. Dramatic conventions are used as tools for the development of language skills, which must be the priority of the ML teacher. There are, for example, opportunities for learners to hear extended narratives in the target language through the use of 'teacher in role' which are supported by the use of mime. Group improvisation facilitates complex sentence- building using the future tense, where less confident learners can be supported by their peers. 


\section{Figure 3}

\section{Crash Landing: a one hour drama for the Foreign Languages classroom}

Topic Area: Holidays

Creative use of language: the drama provides opportunities for pupils to use the language they already know in new and exciting contexts. If they become engaged with the story, it will also encourage them to search for new language. Aim to use only the target language.

Language practised may include: describing holiday locations; describing people; past tenses; future tense; daily routine. In order to make the most of the one hour drama session, it is important to thoroughly revise the main language they will be using beforehand.

\section{Outline lesson plan}

1)Starter activities

- Flashcard Games - Revise key vocabulary (eg.: desert island; winning a competition; luxury hotel; suitcase; letter box.)

- Drama activity: Walk around the room to music. When music stops get into groups of $3 / 5 / 6$ etc.

After a few minutes, ask them to make shapes in their groups (letter box etc.)

\section{2) Building the dramatic frame:}

\section{Entering a competition}

- Distribute blank cards to pupils in groups of 3 or 4.

- Set the scene by explaining that they are a group of people entering a competition to win a holiday in a luxury hotel.

- Their task is to write the competition question(s) and answer(s).Ask them to consider the identity of the group and why they might want to win the holiday. If they are footballers' wives, or cyclists for example, the questions will reflect their common interests. Model the task first. You might want to play some suitable island music as they work!

Presentations Pupils present their questions and answers. The rest of the group try to guess their group identity. When each group has done this, they 'post' the card by handing it to the teacher (or a mock-up post box).

\section{3) Winning a competition}

- Teacher narrates story in TL using visual support, mime ("It's Saturday morning, you are having your breakfast with your group. What are you eating? (Pupils make suggestions).

Suddenly a letter lands on the doormat. It's for you!"

- Return question cards

The teacher calls up one person from each group to collect their letter.

"It's incredible! You have all won a holiday on a Caribbean island! Go and tell your friends!" (Pupils do so using $\mathrm{TL})$.

4) Imagining the holiday of a lifetime

- Group Improvisation: Show a scene depicting how the group imagine their luxury holiday will be. Prepare sentences (3-5) in TL using future tense. Encourage both verbal and physical responses.

\section{5) Introduce dramatic tension}

- Teacher narrates in TL using mime and visuals: "The big day is finally here. The taxi arrives and drives you to the airport. You take your seats and the steward brings your favourite food and drink. The plane takes off. You close your eyes and dream of your holiday at the luxury hotel. Suddenly the plane jolts and starts to descend. It is going to make an emergency landing. When I clap my hands you will find yourself on a desert island. You have survived!"

\section{6) Exploring the desert island}

- Group Task :You have been on the island for a week. What have you discovered? On a large sheet of paper, draw and label a map of the island. Prepare a short description of the island to present to the class orally.

7)The drama can be used as a stimulus for follow-up speaking or writing tasks. Record a TV interview or write a story about your experience. 


\section{Research Methods and Ethics}

These are drawn from action research (Stenhouse, 1975; Elliot, 1991) in that our focus was on gaining critical insights into our own practice in order to improve it. Data was gathered over a period of three years from three successive cohorts of PGCE ML and drama student teachers. We drew on 'naturally occurring' data comprising student teachers' written reflections, their practice-based research and our observations of their teaching. We analysed student responses to the university- based ML/drama seminars through questionnaires which we distributed at the end each seminar which offered opportunities for longer comments. Group interviews were conducted with student teachers from each of the three cohorts (numbering 14, 12 and 16 student teachers in total) and individual interviews with five student teachers and one a former student teacher who has continued to use drama in her classroom practice. The ML student teachers who participated in this project have diverse backgrounds, ages and experiences of language teaching and learning. About 20\% were native speakers of French, German or Spanish. About one third had previous careers in other areas such as international business and a significant proportion have prior experience of teaching EFL abroad. The data was analysed at the end of each year and used to inform the next stage of the project using an action research iterative cycle (Elliot, 1991).We employed progressive focusing' where the collection of data is guided by the developing clarification of themes of enquiry (Hammersley \& Atkinson, 2007, p151).The process of data collection was 'unstructured' in that we did not begin with a pre-defined research design, but allowed it to emerge in response to the data. We were mindful of potential ethical difficulties which might arise in conducting research with our own students and to this end endeavoured to avoid exploiting our position and to ensure that students benefitted from participating.

\section{Research Questions}

Our research focused on three questions:

- RQ1) How did the student teachers view process drama as a potential tool for teaching an additional language? 
- RQ2)What are the barriers to student teachers using process drama as a tool for teaching an additional language

- RQ3) How can they best be supported to surmount these?

\section{Findings}

\section{RQ1) How did the student teachers view process drama as a potential tool for teaching an additional language?}

The questionnaire data shows $100 \%$ student teachers agreed that 'process drama techniques could be integrated into ML teaching'. Their feedback following the University ML/drama sessions was overwhelmingly positive. Having enjoyed the experience of participating in the sessions themselves, they were able to see how this might have a positive effect on their own students:

'I can see how this idea could really motivate these students.'

When asked what the potential benefits might be, many cited 'being creative', 'using language for a purpose', elements which have been identified as being often absent in current practice. They were able to articulate a rationale for using process drama which linked with Ushioda's idea that motivation in language learning is dependent upon expressing personal meanings and identities (Ushioda, 2011):

I like the idea that children can input their own ideas. The drama was not set in tablets of stone.'

'It's not about acting; it's about boosting their confidence in using the language.'

The University drama/ML sessions were seen as positive, enjoyable experiences by almost all of the students. The sessions provided them with alternative models of classroom practice which 
stimulated enthusiasm and confidence and helped develop a clear understanding of the potential benefits of process drama:

'Very innovative. I will definitely try this on my new placement.'

The student teachers were very receptive to the possibilities of using process drama to motivate their pupils, but the gap between their experiences of an idealised 'induction' and the realities of 'initiation' (Stronach, 2009) became apparent when they tried to implement it in practice.

\section{RQ2)What are the barriers to student teachers using process drama as a tool for teaching an additional language?}

Only a small number of student teachers were prepared to try out process drama during their school practicum with the majority preferring to stay within the safer areas of role play and drama games. The data highlights a number of factors which inhibit the transference of a new pedagogical approach from University to the ML classroom including: a fear of relinquishing control of behaviour and of learning, a lack of skills and experience and a lack of time. The data reveals how student teachers struggle to accommodate ecologies of practice within economies of performance.

\section{Maintaining control}

The student teachers were reluctant to cede control of learning to their students and allow them to create their own language, tending to be drawn back towards traditional methods where outcomes are more quantifiable:

'I gave them the story of what was happening and we looked at the translation.'

'What we did was create a situation in a Spanish café....They had to learn some dialogue, they had to read aloud...practise how to say some high frequency words.' 
They expressed a fear that introducing their students to a new way of working in language lessons would cause discipline to break down:

'My Year 9 (class of 13-14 year olds) wouldn't take it seriously; they would rip it to pieces.'

They had doubts concerning their ability to deal with unexpected outcomes, particularly with classes they did not know so well. Their vulnerability and insecurity regarding their professional identity (Hargreaves, 2002) is apparent:

'It's scary not knowing how it's going to go.'

'I would like to know how the group will react doing such an activity, where they have to move around.'

One student teacher who had experienced success with a scripted drama (narration accompanied by group mime) articulates her quandary in balancing students' enjoyment with the perceived need to curb their freedom:

'I think they struggled with the amount of freedom they were given. I had to rein it back in quite a lot. But they really enjoyed it.'

\section{Linguistic constraints}

The ML student teachers prioritised linguistic outputs in the drama work they did in the classroom with relatively little consideration being given to 'dramatic imperatives' (Rothwell, p.591). Discrete elements of drama, such as games, mime or the use of conventions which could easily be incorporated into language lessons were more commonly used: 
'We looked at the words in the story, at the phonetic sounds of the words...then we put mime to the main word...Then, in groups, they put together their own drama piece using the narrative script they are given. They really enjoy it.'

The view that process drama was suitable only for older students who had already acquired a good level of linguistic competence was evident (a view not borne out in our experience of coteaching mixed ability groups of 11-12 year old students). They expressed concern that they lacked the experience and expertise to judge the linguistic content of the lesson:

'Great idea, but are they able to do it in the target language?'

'I really liked what we did in University.... but I don't know that the children would have the language skills to do that.'

A great deal of attention was given to anticipating the language required by students and structuring the drama narrative to ensure it did not exceed their linguistic capacity. In particular they needed advice on structuring grammatical and lexical content which was most effective when lessons were co-planned and taught with the university ML tutor.

\section{Time constraints}

Lesson planning was more time consuming than for a 'normal' ML lesson which deterred some student teachers. They were very conscious of more pressing curricular priorities and tended to see drama as a supplementary 'fun' activity. The view that real language learning is about 'covering the topics' was evident: here economies of performance hold sway. One student teacher said that she was discouraged from continuing her drama work because her class of 1314 year olds were allocated just one 50 minute ML lesson per week. Her view, expressed below, was shared by many:

'Drama can take up so much time. We have to get through the topics.' 
It is clear from the evidence that not all schools are open to creative approaches, and that student teachers on placement in these schools feel unable to innovate:

'The view of the teachers seems to be 'we have found what works'. It is difficult to contradict them. I can't sell the idea of drama in the department I am in.'

Drama, then is perceived to be an enjoyable activity which allows students more freedom but takes time away from the 'real' business of language learning. The student teacher is caught between economies of performance and ecologies of practice which draw them away from enjoyable but time-consuming pedagogical approaches towards more 'efficient' methods which are contained within a narrow specification of subject content because of the certainty it appears to offer (Stronach et al., 2002, p.124).

\section{RQ3) How can student teachers best be supported?}

The student teachers most likely to incorporate process drama into their practice were those who had prior experience of drama and a small number who were placed in schools where the Performing Arts had a high profile. One ML teacher was able to further develop her use of process drama during her first year of teaching with the support of a fellow drama teacher. She describes the advantages of being able to capitalise on students' knowledge of drama conventions and terminology in her ML lessons:

'Being a performing arts school... a lot of activities they do in other subjects are drama based as well, so they are already used to drama.'

There is evidence that cross- subject seminars can be a springboard for student teachers to develop more creative approaches to their teaching on placement. Questionnaire responses show that they appreciated having opportunities to 'share different ideas and viewpoints' as well as learn new teaching strategies. As one student commented, following a cross-subject session: 
'ML trainees could contribute to language and drama trainees could come up with ideas on how to incorporate it creatively.'

The challenges of creating a genuinely reciprocal relationship were also highlighted. For example, the challenge of negotiating the focus for the lesson was a particular issue with a number of ML student teachers noting that there was 'too much drama' and not sufficient emphasis on language content.

It would possibly have been better if the drama student teachers had put more languages into their work as well as just putting drama into our (ML work), but certainly they have helped us a lot.'

A small number of ML students said they felt 'uncomfortable' working with drama trainees. One commented that drama trainees are "over the top and over-act" which led to tutor reflection on the need in the future to allow for discussion of not only affinity, but difference in terms of perceived and portrayed subject teachers personal and professional identities. However, there is evidence that genuine reciprocity is achievable and mutually enriching. One student ML teacher paired up with a drama student teacher who was in the same school. Together they planned and taught successful cross- curricular lessons on placement:

I can see loads of ways in which drama can be used to teach languages. I am learning French at the moment so I can do more.'

'I am learning new drama techniques and I think this has definitely helped my selfconfidence.'

The principle factor affecting the successful implementation of process drama in the ML classroom was having specialist support from peers, tutors or mentors. Such support was welcomed by student ML teachers. In particular they benefited from guidance on managing groups of students in an open drama space. One student reported that watching a drama student teacher had helped: 
'I copied it. This gave me the confidence to explore new techniques.'

A number of ML student teachers elected to implement a drama project for a small-scale practitioner research project which they undertake as an academic assignment. This acted to encourage students to be more innovative:

'For my research project, I did a drama lesson where everything was moved out of the way...the response I got encouraged me...I have seen how it works and I will do it again.'

When student teachers were able to experience success in the form of positive responses from their students they were more inclined to persevere. Evidence gathered from observations of lessons indicates that there are benefits in terms of motivation and rich opportunities for creative language use. The atmosphere in the classroom was one of great excitement and a feeling of achievement as students were able to use the language they knew and search for new words to create an imaginative story:

'Our group was very funny; I loved every bit of it. The French we spoke was good!' (Year 7 student)

\section{Concluding Discussion}

The willingness of student teachers to engage in dramatic storytelling in a foreign language has been marked. We are convinced of the value of introducing creative approaches which allow them to see possibilities beyond traditional subject boundaries and facilitate a critical engagement with accepted practice. The conflicts and dilemmas which arise as a result of the gap between what is perceived as a 'generic and idealised' practice and the 'unpredictable and singularised' demands of real performance (Stronach, 2009, p168) provide spaces for them to investigate their professional identities. 
We conclude that whilst the benefits of using process drama as a tool for language learning were evident, the individual student teacher's capacity to use it was dependent on their personal experiences and dispositions and the extent to which their efforts were supported in school (Trent 2014). The establishment of links between subject disciplines, both in university and in school was a key feature of successful implementation as was the willingness of practitioners of both drama and ML to work together to forge new practices. We suggest that for process drama to become part of the language teacher's repertoire a degree of compromise is required by practitioners of both subject disciplines. We found that where ML student teachers were able to witness the value of the drama as a tool for achieving the linguistic outcomes within the prescribed curriculum, they were more willing to continue with it. We suggest that the compromises we arrived at in our project, whilst not offering the 'full promise' of working with drama and additional language learning (Dunn and Stinson, 2011, p.618) do provide possible ways forward for the development of innovative practices which might survive. The majority of the student teachers said that they would be interested in trying out the approach in the future, indicating that a seed has been sown which might grow if it can be nurtured in school.

Presenting a strong case for the value of the approach necessitates acknowledging not only the euphoria but the un-comfortableness in crossing the boundaries between subject pedagogies for the student teacher. We have come to view the gap between the 'possibilities of induction' and the 'experience of initiation' (Stronach, 2009) not as a comfortable professional place in which innovation is managed, but rather a site of possibility with all the accompanying risks and uncertainty associated with change. We envisage the Modern Languages / Drama border as one site in initial teacher education where student teachers can question their subject identities and practices and nurture an understanding of how to live with and learn through the disparate allegiances of 'ecologies of practice' and 'economies of performance'. We propose that the coconstruction of creative approaches can bring about a more motivating and enjoyable experience of teaching and learning languages which is in the common interest of both teachers and learners. 


\section{References}

Adams, J. and Owens, A. 2016. Creativity, Education and Democracy: the practices and politics of learning in the arts, London: Routledge.

Adnett, N. \& Hammersley- Fletcher, L. (2009). Empowerment or prescription? Workforce remodeling at the national and school level. Educational Management Administration and Leadership, 37, 180-197

Ball, S. J. (2003). The teacher's soul and the terrors of performativity. Journal of Education Policy, 18(2), 215-228.

Boal, A. 1979. Theatre of the Oppressed. Trans. Mc Bride, L. London: Pluto Press.

Bräuer, G. (Ed.).2002. Body and Language: intercultural learning through drama. Westport, USA: Ablex.

Chang, L.S. 2012. Dramatic Language Learning in the Classroom. In Winston, J. (Ed.) (2012) Second Language Learning Through Drama. Oxon: Routledge.

CILT/ALL/ISMLA. 2009. Language Trends Secondary Survey. London :CILT (Centre for Information on Language Teaching).

Coleman, J. A , Galaczi,A.and Astruc, L. 2007. Motivation of UK school students towards foreign languages: a large scale survey at KS3 .Language Learning Journal, 35: 2, 245-281.

Day, C., Stobart, G., Sammons, P, Kington, G. and Gu Q. 2007.Teachers Matter: connecting lives, work and effectiveness. Maidenhead: Open University Press.

DeCoursey, M. and Trent, J. 2016. Stultification and the negotiation of meaning: drama for second language education in Hong Kong Schools. Research in Drama Education: The Journal of Applied Theatre and Performance, 21:4, 524-534.

Dörnyei, Z. 2001. Motivational Strategies in the Language Classroom. Cambridge: Cambridge University Press.

Drain, R. (Ed.).1995. Twentieth Century Theatre: A source book. London: Routledge. 
Dunn, J. and Stinson, M. 2011. Not without the Art! The importance of teacher artistry when applying drama as pedagogy for additional language learning. Research in Drama Education: The journal of Applied Theatre and Performance, 16:4,617-633.

Elliot, J. 1991. Action Research for Educational Change. Milton Keynes: Open University Press.

Enever, J. 2009. Languages, Education and Europeanisation. In Dale, R. and Robertson, S. (2009). Globalisation and Europeanisation in education (pp.179-192). Oxford: Symposium Books.

Fleming, M. 2001. Teaching Drama in Primary and Secondary Schools. London: David Fulton.

Fleming, M. 2006. Drama and language teaching: the relevance of Wittgenstein's concept of language games. Humanising Language Teaching, 8:4, 97-110.

Freire, P.1972. Pedagogy of the Oppressed. Harmondsworth:Penguin.

Giebert, S. 2014. Drama and theatre in teaching foreign languages for professional purposes. Recherche et pratiques pédagogiques en langues de spécialité, 33:1, 138-150.

Hammersley, M. \& Atkinson, P. (2007). Ethnography: Principles and Practice. (3rd Ed.) London and New York: Routledge.

Hargreaves, A. 2002. Teaching in a Box: Emotional geographies of teaching. In Sugrue, C. and Day, C. (Eds.). 2002. Developing Teachers and Teaching Practice: International research perspectives. London: Routledge.

Harris, V., Burch, J., Jones, B. and Darcy, J. 2001. Something to say? Promoting spontaneous classroom talk. London: CILT.

Heikkinen, H. 2005. Draama-Kasvatus:Opetusta, Taidetta, Tutkimista. Jyvaskyla: Minerva.

Jones, M. (2000).Trainee teachers' perceptions of school-based training in England and Germany with regard to their preparation for teaching, mentor support and assessment. Mentoring \& Tutoring: Partnership in Learning, 8(1), 63-80.

Kao, S.M. and O'Neill, C. 1998. Words into Worlds: Learning a second language through process drama. Stamford, USA: Ablex.

Littlewood, W. 1984. Foreign and Second Language Learning. Cambridge University Press 
Liu, J. 2002. Process Drama in Second and Foreign Language Classrooms. In Bräuer, G. (Ed.). 2002. Body and Language: intercultural learning through drama. Westport, USA: Ablex.

Macaro, E. 2003.Teaching and Learning a Second Language: A guide to recent research and its applications. London: Continuum.

Markee, N. 2001.The diffusion of innovation in language teaching. In Innovation in Language Teaching: a reader. Ed. Hall, D and Hewings, A. 118-26. London: Routledge.

Mitchel, R. 2003. Rethinking the concept of progression in the National Curriculum for Modern Foreign Languages: a researcher perspective. Language Learning Journal, 27(15):25-33.

Neelands, J. 2002. 11/09: The Space in our Hearts. Drama Magazine. Summer. pp.4-11.

Neelands, J. 1992 Learning through Imagined Experience, Sevenoaks: Hodder \& Stoughton.

Office for Standards in Education (Ofsted) . 2011. Modern Languages Achievement and Challenge 2007-2010. Manchester: Ofsted Publications.

O’Neill, C. 1995. Drama Worlds. Portsmouth: Heinemann.

O'Toole, J. 1992. The Process of Drama: Negotiating Art and Meaning, Lonodn:Routledge.

Owens, A. and Barber, K. 2001. Mapping Drama. Carlisle: Carel Press.

Piazzoli, E. 2011. Process drama: the use of affective space to reduce language anxiety in the additional language learning classroom. Research in Drama Education: The journal of Applied Theatre and Performance, 16:4,557-573.

Prochazka, A. (Ed).2007. Drama In Modern Language Teaching, Part1,DramapädagogikMethodenzusatzausbildung in englischer Sprache. Vienna: Pädagogisches Institut des Bundes in Wien.

Robinson, K. (2011). Out of our Minds: Learning to be Creative. Chichester: Capstone.

Rothwell, J. 2011. Bodies and Language: process drama and intercultural language learning in a beginner language classroom. Research in Drama Education: The journal of Applied Theatre and Performance, 16:4,575-594.

Sommers, J. 1994. Drama in the Curriculum. London: Cassell. 
Stenhouse, L. 1975. The teacher as researcher. In Stenhouse, L. (Ed.)(1975). An introduction to curriculum research and development (pp.142-65). London: Heineman.

Stinson, M. and Freebody, K. 2006. The DOL Project: An investigation into the contribution of process drama to improved results in English oral communication. Youth Theatre Journal, 20: $27-41$.

Stinson, M. and Winston, J. 2011. Drama education and second language learning: a growing field of practice and research. Research in Drama Education: The journal of Applied Theatre and Performance, 16:4,479-488.

Stronach, I., Corbin, B. ,McNamara, O., Starck, S. and Warne, T. 2002. Towards an uncertain politics of professionalism: teacher and nurse identities in flux. Journal of Education Policy,17:1, 109-138.

Stronach, I. 2009. Globalizing education, educating the local: how method made us mad. Routledge: London.

Tickle, L. (2001).Teacher Induction: The Way Ahead. Buckingham/Philadelphia: Open University Press.

Trent, J. 2014. Innovation as identity construction in language teaching and learning: case studies from Hong Kong. Innovation in Language Learning and Teaching,8:1,56-78.

Ushioda, E. 2011. Why autonomy? Insights from motivation theory and research. Innovations in Language Learning and teaching, 5:2,221-232.

Winston, J.2012. (Ed.) Second Language Learning Through Drama. Oxon: Routledge. 